\title{
War, weapons and watchdogs: an assessment of the legality of new weapons under international human rights law
}

\author{
Helin M Laufer \\ King's College London, UK \\ This paper will critically analyse the International Committee of the Red Cross' new weap- \\ ons review and emphasise the importance of considering human rights in the assessment of the \\ legality of weapons. Further, the paper will illustrate this practically by analysing the legality \\ of drones and killer robots from the perspective of the right to life and the prohibition against \\ torture and cruel, inhuman and degrading treatment.
}

Keywords: international humanitarian law, human rights, International Committee of the Red Cross, weapons, drones, killer robots

\section{INTRODUCTION}

'The main foundations of every state ... are good laws and good arms - you cannot have good laws without good arms, and where there are good arms, good laws inevitably follow.'

Niccolo Machiavelli (1469-1527)

The law of weapons is among the oldest of the laws of armed conflict, yet one of the least effective ones. As weaponry advanced rapidly in the 20th century, the law struggled to keep up with these developments. The emergence of modern lethal weapons requires States to achieve the right balance between their military interests and legal obligations more than ever before. ${ }^{1}$

The starting point of this paper is the International Committee of the Red Cross' (ICRC) guide to the legal review of new weapons (New Weapons Review). ${ }^{2}$ While the ICRC has provided useful legal guidelines for States in their acquisition and use of new weapons, it has failed to consider the legality of such weapons under international human rights law (IHRL). The first part of the paper will criticise the ICRC's approach by demonstrating that IHRL is part of the law applicable in armed conflict and should, therefore, have been included in the ICRC's guide.

The second part of the paper will take the ICRC's effort to issue guidelines further and provide a model analysis of the legality of new weapons under IHRL. The focus

1. C Greenwood, 'The Law of Weaponry at the Start of the New Millennium' (1998) 71 International Law Studies 185.

2. International Committee of the Red Cross (ICRC), 'A Guide to the Legal Review of New Weapons, Means and Methods of Warfare: Measures to Implement Article 36 of Additional Protocol I of 1977' (January 2006) <www.icrc.org/eng/resources/documents/publication/ p0902.htm> accessed 15 March 2017 (New Weapons Review). 
will be on the right to life $\mathrm{e}^{3}$ and the prohibition of torture and cruel, inhuman or degrading treatment (CIDT). ${ }^{4}$ The analysis will be a practical one and focus on the capacity of unmanned aerial vehicles (drones) and autonomous robot systems (killer robots) to comply with IHRL. Although such weapons are also employed in circumstances that Amnesty International labelled as 'far from the battlefield' ${ }_{5}^{5}$ this paper will consider their legality solely in armed conflict.

\section{THE ICRC'S NEW WEAPONS REVIEW: A CRITICAL APPRAISAL}

\subsection{The ICRC's incomplete guide}

The right of States 'to choose methods or means of warfare is not unlimited' ${ }^{6}$ Weapons that 'cause superfluous injury or unnecessary suffering' are forbidden. ${ }^{7}$ Article 36 of Additional Protocol I further states that the legality of a weapon must be determined in relation to the Protocol or 'any other rule of international law applicable'. ${ }^{8}$

The ICRC used Article 36 as a starting point to issue a set of guidelines for States to apply in order to determine the legality of new weapons. Correctly recognising that all applicable international law must be considered in this assessment, ${ }^{9}$ the ICRC did not solely rely on international humanitarian law (IHL), the law governing the conduct of hostilities in armed conflict. ${ }^{10}$ It also considered specialised weapons conventions, ${ }^{11}$ customary prohibitions of specific weapons ${ }^{12}$ and relevant international criminal law provisions. ${ }^{13}$ However, IHRL contained within both treaties and custom was entirely absent from consideration. As will be demonstrated later

3. Universal Declaration of Human Rights (adopted 10 December 1948) UNGA Res 217 A (III) (UDHR) art 3; International Covenant on Civil and Political Rights (adopted 16 December 1966, entered into force 23 March 1976) 999 UNTS 171 (ICCPR) art 6(1); European Convention for the Protection of Human Rights and Fundamental Freedoms (European Convention on Human Rights, as amended) (ECHR) art 2; American Convention on Human Rights (adopted 22 November 1969, entered into force 18 July 1978) 1144 UNTS 123 (ACHR) art 4; African Charter on Human and Peoples' Rights (adopted 27 June 1981, entered into force 21 October 1986) (1982) 21 ILM 58 (ACHPR) art 4.

4. Convention against Torture and Other Cruel, Inhuman or Degrading Treatment or Punishment (adopted 10 December 1984, entered into force 26 June 1987) 1465 UNTS 85 (CAT) arts 2, 16; ICCPR art 7; ECHR art 3; ACHPR art 5.

5. Amnesty International, 'United States of America: "Targeted Killing" Policies Violate the Right to Life' (2012) <www.amnestyusa.org/sites/default/files/usa_targeted_killing.pdf> accessed 15 March 2017 (AI, 'Targeted Killings') 1-2.

6. Protocol Additional to the Geneva Conventions of 12 August 1949, and relating to the Protection of Victims of International Armed Conflicts (Protocol I) (adopted 8 June 1977, entered into force 7 December 1978) 1125 UNTS 3 (AP I) art 35(1); Hague Convention (IV) respecting the Laws and Customs of War on Land and its annex: Regulations concerning the Laws and Customs of War on Land (adopted 18 October 1907, entered into force 26 January 1910) 36 Stat. 2277 art 22.

7. AP I (n 6) art 35(2).

8. Ibid art 36.

9. Ibid.

10. New Weapons Review (n 2) 10, 15.

11. Ibid 12 .

12. Ibid 13, 16.

13. Ibid 13 . 
in this paper, IHRL also applies in armed conflict, thus the failure to consider it is a significant gap in these otherwise comprehensive guidelines. Although the ICRC urges States to be active in the assessment of the legality of new weapons, publish reports and share their findings on such weaponry, ${ }^{14}$ without a truly holistic set of legal guidelines, it is difficult to see how States can achieve this. ${ }^{15}$

Unfortunately, even in its later work on new weapons, whilst it has considered ethics, ${ }^{16}$ the ICRC has not included an IHRL perspective. ${ }^{17}$ The only mention of human rights was made by Peter Asaro at an ICRC expert meeting. ${ }^{18}$ He explained that to assess the moral implications of new weapons, States must analyse IHRL as well. ${ }^{19}$ Despite this step forward, the ICRC has recently taken one back when it failed to regard IHRL once more in its April 2016 paper on autonomous weapons systems. ${ }^{20}$

Thus, despite recognising that all applicable international law must be assessed to determine the legality of new weapons, the ICRC has still failed to include human rights in this determination. Although this paper will argue that this is a legally incorrect approach, there are reasonable explanations for the ICRC's position. Article 36 is derived from Article 35(1) of Additional Protocol I (AP I), which restricts the right of States to choose their means of warfare. As the ICRC considers the latter provision to be the 'basic tenet' of IHL, the ICRC's heavy reliance on IHL is understandable. ${ }^{21} \mathrm{IHL}$ has been tailored to assist States in obtaining their desired military outcomes while employing weapons compliant with international law. ${ }^{22}$ IHRL is, however, less specific on such matters and cannot always provide adequately complex and sophisticated answers to questions regarding what is an appropriate use of weapons. ${ }^{23}$

\footnotetext{
14. Ibid 47.

15. Greenwood (n 1) 221.

16. ICRC, 'Views of the ICRC on Autonomous Weapon System' (11 April 2016) <www.icrc. org/en/document/views-icrc-autonomous-weapon-system> accessed 15 March 2017 (ICRC, 'Views of the ICRC') 4-6.

17. The ICRC's relevant subsequent work addresses a wide range of issues relating to weapons, such as humanitarian or ethical considerations. However, no specific mention to human rights is made in the context of weapons. See ICRC, 'New Technologies and The Modern Battlefield: Humanitarian Perspectives' (2012) <www.app.icrc.org/e-briefing/new-tech-modern-battlefield/ index.html?mc_cid=5a90fef39a\&mc_eid=62e45022af $>$ accessed 15 March 2017; ICRC, 'Autonomous Weapon Systems - Q \& A' (12 November 2014) <www.icrc.org/en/document/ autonomous-weapon-systems-challenge-human-control-over-use-force> accessed 15 March 2017 (ICRC, 'Q \& A'); ICRC, 'Autonomous Weapon Systems: Is it Morally Acceptable for a Machine to Make Life and Death Decisions?' (13 April 2015) <www.icrc.org/en/document/ lethal-autonomous-weapons-systems-LAWS> accessed 15 March 2017 (ICRC, 'Autonomous Weapons Systems'); ICRC, 'Weapons: ICRC Statement to the United Nations, 2015' (15 October 2015) <www.icrc.org/en/document/weapons-icrc-statement-united-nations-2015> accessed 15 March 2017.

18. P Asaro, 'Ethical Issues Raised by Autonomous Weapon Systems' in ICRC, 'Autonomous Weapon Systems: Technical, Military, Legal and Humanitarian Aspects' (26-28 March 2014) $<$ www.icrc.org/en/download/file/1707/4221-002-autonomous-weapons-systems-full-report. pdf $>$ accessed 15 March 2017, 49.

19. Ibid 51.

20. ICRC, 'Views of the ICRC' (n 16).

21. New Weapons Review (n 2) 3.

22. Ibid 4.

23. N Lubell, 'Challenges in Applying Human Rights Law to Armed Conflict' (2005) 87 No 860 International Review of the Red Cross 741; E Wilmshurst, International Law and the Classification of Conflicts (OUP, Oxford 2012) 93.
} 
Moreover, the majority of current armed conflicts are non-international, ${ }^{24}$ involving non-state actors who cannot be held accountable for human rights violations under IHRL treaties. ${ }^{25}$ As they are bound by IHL only, the focus remains on developing and strengthening IHL rules. ${ }^{26}$ These arguments are based on the fact that IHL is better equipped to regulate the use of weapons. However, this does not automatically render IHRL practically inapplicable or without normative use.

It is important to note that, while the ICRC has not considered human rights in its assessment of the legality of new weapons, it does recognise the applicability of human rights in armed conflict. ${ }^{27}$ Thus, the purpose of this paper is not to criticise the ICRC's general approach to human rights in war. The intention here is rather to emphasise that such human rights considerations must be regarded in all circumstances of armed conflicts, even in the narrower context of the law of weapons. The vague acceptance of the general applicability of human rights in armed conflict is insufficient. To enforce international law correctly, it is necessary to go further and apply human rights considerations in all practical contexts relating to armed conflicts - including the use of new weapons.

\subsection{The applicability of IHRL in armed conflict}

It has been firmly established that IHRL does apply in armed conflict. The International Court of Justice (ICJ), regional human rights courts, the Human Rights Committee (HRC) and the International Law Commission accept that States' human rights obligations under IHRL treaties and custom continue to apply in times of hostilities. ${ }^{28}$ The ICJ's Wall Advisory Opinion clarifies how IHL and IHRL interact: both branches of the law can apply exclusively or simultaneously. ${ }^{29}$

The question of how IHRL and IHL will interact when they apply simultaneously has two possible answers. The HRC's 'belt and suspenders' approach suggests that the two laws are 'additive in nature' ${ }^{30}$ In other words, IHL and IHRL are complementary

24. United Nations General Assembly, 'Report of the Special Rapporteur on the Promotion and Protection of Human Rights and Fundamental Freedoms While Countering Terrorism' (2012) UN Doc A/HRC/20/14, 4; A Clapham, Human Rights Obligations of Non-State Actors (OUP, Oxford 2006) 25-59; P Alston, 'The Not-a-Cat Syndrome: Can the International Human Rights Regime Accommodate Non-State Actors?' in P Alston (ed), NonState Actors and Human Rights (OUP, Oxford 2005) 3-36.

25. Ibid.

26. Ibid.

27. ICRC, 'IHL and Human Rights Law' (29 October 2010) <www.icrc.org/eng/war-and-law/ ihl-other-legal-regmies/ihl-human-rights/overview-ihl-and-human-rights.htm> accessed 28 February 2017.

28. Legality of the Threat or Use of Nuclear Weapons (Advisory Opinion) [1996] ICJ Rep 66, [25] (Nuclear Weapons); Legal Consequences of the Construction of a Wall in the Occupied Palestinian Territory (Advisory Opinion) [2004] ICJ Rep 136, [106] (Wall); Armed Activities on the Territory of the Congo (DRC v Uganda) (Merits) [2005] ICJ Rep 168, [206] (Armed Activities); Coard v United States (1999) I/ACommHR, Rep No 109/99 (Coard), para 39; Hassan v United Kingdom App No 29750/09 (ECtHR, 16 September 2014), para 87 (Hassan); International Law Commission, 'Fragmentation of International Law: Difficulties Arising from the Diversification and Expansion of International Law' (1 May - 9 June and 3 July - 11 August 2006) UN Doc A/CN.4/L.682, para 104.

29. Wall (n 28) [106].

30. W Schabas, 'Lex Specialis? Belt and Suspenders? The Parallel Operation of Human Rights Law and The Law of Armed Conflict, and The Conundrum of Jus ad Bellum' (2007) 40 Israel L 
and thus apply equally. ${ }^{31}$ However, this approach generates uncertainty as it does not offer any guidelines in situations where the two bodies of law conflict. ${ }^{32}$ The more widely accepted interpretation of the IHL-IHRL relationship is that the principle of lex specialis derogat legi generali governs situations of simultaneous application. ${ }^{33}$ According to the ICJ and all relevant courts, the lex generalis - IHRL - will be interpreted in light of the lex specialis - IHL. ${ }^{34}$ By considering both laws, while using IHL as an interpretational tool, the potentially opposing interests of the two laws can be reconciled. ${ }^{35}$ For instance, when assessing potential violation of the right to life, deprivation of life will be allowed provided it is not arbitrary; and the concept of arbitrariness will then be assessed according to IHL principles. ${ }^{36}$

While this interpretational approach is satisfying, Silvia Borelli rightly notes that it is incorrect to analyse it through the lex specialis lens. ${ }^{37}$ The lex specialis dictum 'implies the (partial or total) disapplication or displacement of the general law in favor of the special law' ${ }^{38}$ The ICJ's previous interpretation of lex specialis is thus a misuse of this general principle of law, ${ }^{39}$ as IHRL is not disapplied in armed conflict, but coexists with IHL. ${ }^{40}$ Accordingly, the ICJ has in fact not been relying on lex specialis, but rather on 'the principle of systematic interpretation' enshrined Article 31(3)(c) of the Vienna Convention on the Law of Treaties (VCLT), ${ }^{41}$ whereby 'any relevant rules of international law applicable' shall be considered in the interpretation of human rights treaty provisions. ${ }^{42}$ Thus, when the ICJ suggested that the human right to life was to be interpreted in light of IHL, it was essentially applying the VCLT, not the lex specialis principle.

Furthermore, it is firmly established in international law that States retain human rights obligations outside their territories. ${ }^{43}$ Therefore, in light of the clear application

Rev 593, 593; United Nations Human Rights Committee, 'General Comment No. 31: The Nature of the General Legal Obligation Imposed on States Parties to the Covenant' (2004) UN Doc CCPR/C/21/Rev.1/Add. 1326 (GC 31) para 11.

31. Schabas (n 30) 597.

32. Ibid 612 .

33. Nuclear Weapons (n 28) [25]; Wall (n 28) [106]; Economic and Social Council, 'Working Paper on the Relationship between Human Rights Law and International Humanitarian Law' (21 June 2005) UN Doc E/CN.4/Sub.2/2005/14, para 57.

34. Ibid.

35. Schabas (n 30) 610.

36. Nuclear Weapons (n 28) [25].

37. S Borelli, 'The (Mis)-Use of General Principles of Law: Lex Specialis and the Relationship between International Human Rights Law and the Laws of Armed Conflict' in L Pineschi (ed), General Principles of Law - The Role of the Judiciary (Springer, New York 2015) 266.

38. Ibid 273.

39. Since 2005, there has been a shift in the ICJ's position, whereby the Court is moving away from the lex specialis dictum. In Armed Activities and the Croatian Genocide Case, the Court did not make any reference to lex specialis. See Armed Activities (n 29); Application of the Convention on the Prevention and Punishment of the Crime of Genocide (Croatia v Serbia) (Merits) <www.icj-cij.org/docket/files/118/18422.pdf> accessed 15 March 2017 [474]; Borelli (n 37) 276-7.

40. Borelli (n 37) 268.

41. Ibid 274.

42. Vienna Convention on the Law of Treaties (adopted 23 May 1969, entered into force 27 January1980) 1155 UNTS 33 (VCLT) art 31(3)(c).

43. Wall (n 28) [111]; Armed Activities (n 28) [216]; Coard (n 28), para 37; Al-Skeini and Others v United Kingdom App No 55721/07 (ECtHR, 7 July 2011), para 131; Jaloud v 
of IHRL extraterritorially and in armed conflict, the ICRC's New Weapons Review is indeed incomplete.

\subsection{The practical relevance of a human rights assessment}

Further, the ICRC should have considered IHRL because its applicability in armed conflict has a particular practical relevance, especially in the context of new weapons. First, IHRL has filled some of IHL's gaps, for instance, by requiring the investigation of certain losses of life and severe injuries. ${ }^{44}$ In light of the constant deaths caused by lethal weapons such as drones, such a requirement is of paramount importance to ensure compliance with 'international human rights and humanitarian law and other basic rules of public international law'. ${ }^{45}$ Secondly, the IHRL regime allows stronger litigation, giving victims of human rights violations a remedy against their own State where the government is the perpetrator. ${ }^{46}$ This is not possible under IHL. ${ }^{47}$

Most importantly, under IHRL, all individuals are considered equal. ${ }^{48}$ Regardless of how the conflict is classified under IHL and the ambiguity of individuals' battlefield status ${ }^{49}$ the applicability of IHRL ensures that everyone receives an equal minimum standard of protection in armed conflict. ${ }^{50}$

\section{THE LEGALITY OF NEW WEAPONS UNDER IHRL}

\subsection{Illegality through the nature or the use of a weapon}

As the ICRC rightly explains, 'a weapon can be unlawful in itself, or it can be unlawful only under certain conditions' ${ }^{51}$ In other words, Article 36 seeks to prevent the acquisition either of weapons which violate international law inherently, through their very nature - meaning that their every use is unlawful $;{ }^{52}$ or those that only violate

Netherlands App No 47708/08 (ECtHR, 20 November 2014), para 139; Montero v Uruguay (1982) 2 Selected Decisions of the Human Rights Committee 136, para 5; GC 31 (n 30), para 10.

44. S Sivakumaran, 'Re-envisaging the International Law of Internal Armed Conflict' (2011) 22(1) EJIL 219, 235; UNGA, 'Report of the Special Rapporteur on the Promotion and Protection of Human Rights and Fundamental Freedoms while Countering Terrorism' (2014), UN Doc A/HRC/25/59.

45. AI, 'Targeted Killings' (n 5) 8.

46. GC 31 (n 30) para 2, 16; UNGA Res 60/147 (16 December 2005) UN Doc A/RES/60/147.

47. Ibid.

48. UDHR art 5; ICCPR art 26; ACHR art 2; ACHPR art 3.

49. N Melzer, 'Interpretive Guidance on the Notion of Direct Participation in Hostilities under International Humanitarian Law' (ICRC, May 2009) <www.icrc.org/eng/assets/files/other/icrc002-0990.pdf> accessed 15 March 2017, 43.

50. N Jayawickrama, The Judicial Application of Human Rights Law: National, Regional and International Jurisprudence (CUP, Cambridge 2002) 816.

51. New Weapons Review (n 2) 7; Y Sandoz, C Swinarski, B Zimmermann, Commentary on the Additional Protocols of 8 June 1977 to the Geneva Conventions of 12 August 1949 (Martinus Nijhoff Publishers, Leiden 1987) para 1402.

52. New Weapons Review (n 2) 4. 
international law when they are used in a non-compliant manner - meaning that their use is unlawful only in some circumstances. ${ }^{53}$

The paper will further demonstrate that, since there are, in theory, situations where drones and killer robots can comply with all relevant norms of international law, these weapons are not inherently unlawful. However, the improper use of drones and killer robots can result in the violation of the right to life and the prohibition of torture and CIDT.

Furthermore, analysing these new weapons through the prism of the right to life and the prohibition of torture is appropriate for two reasons. First, it is obvious that these are the two human rights principally and immediately engaged when drones or killer robots are used. Secondly, these fundamental rights have been tactically chosen to highlight the grave implications such weapons may have. It is thus imperative to consider these two basic human rights in particular, as their breach directly affects an individual's very existence and human dignity.

\subsection{Drones and killer robots: definitions and background}

Drones constitute aircraft "controlled by "pilots" from the ground or, increasingly, autonomously following a pre-programmed mission'. ${ }^{54}$ They are not explicitly prohibited in treaties or custom. ${ }^{55}$ However, drone strikes are intended to be lethal. ${ }^{56}$ For instance, the United States of America's (USA) 364 drone strikes in Pakistan in 2004-2013 ${ }^{57}$ led to over 4700 deaths. ${ }^{58}$ Although drones have also been employed in peacetime, ${ }^{59}$ this paper will only assess their legality in armed conflict.

Killer robots 'independently search for, identify and attack targets without human intervention'. ${ }^{60}$ The development of killer robots has been criticised vehemently, as 'there is a sense of deep discomfort with the idea of any weapon system that places the use of force beyond human control'. ${ }^{61}$ Since they have not been used in combat situations before but continue to be developed technologically, acquiring increased mobility, ${ }^{62}$ killer robots are highly unpredictable weapons. ${ }^{63}$ Thus, the need for an assessment of their legality has never been greater. ${ }^{64}$

53. Ibid.

54. Drone Wars UK, 'What Are Drones?'<https://dronewars.net/aboutdrone/> accessed 15 March 2017.

55. J Pejic, 'Extraterritorial Targeting by Means of Armed Drones: Some Legal Implications' (2015) 893 International Review of the Red Cross 67, 69.

56. AI, 'Targeted Killings' (n 5) 2.

57. Ibid.

58. AI, “Will I Be Next?" - US Drone Strikes in Pakistan' (22 October 2013) <www.amnestyusa. org/sites/default/files/asa330132013en.pdf > accessed 15 March 2017 (AI, 'US Drone Strikes') 13.

59. Ibid.

60. ICRC, 'Q \& A' (n 18) 1.

61. ICRC, 'Autonomous Weapons Systems' (n 18).

62. 'Key Areas for Debate on Autonomous Weapons Systems' (Article 36, May 2014) <www. article36.org/wp-content/uploads/2014/05/A36-CCW-May-2014.pdf> accessed 15 March 2017 (Key areas for debate) 1.

63. ICRC, 'Views of the ICRC' (n 17) 3.

64. Ibid. 


\subsection{The right to life}

\subsubsection{The law}

'A right of the utmost gravity', ${ }^{65}$ the right to life is an absolute non-derogable right. ${ }^{66}$ Thus, it is tempting to immediately assume a violation of the right to life when lethal weapons are employed. ${ }^{67}$ However, not all deprivations of life are unlawful. ${ }^{68}$ The right is violated only if a deprivation of life is arbitrary. ${ }^{69}$ While the concept of arbitrariness is not expressly defined ${ }^{70}$ according to the lex specialis principle or, more accurately, the systematic interpretative approach under the VCLT, the notion of arbitrariness will be determined by reference to IHL. ${ }^{71}$ In other words, if the use of a weapon that results in a deprivation of life complies with the basic IHL principles distinction, ${ }^{72}$ unnecessary suffering, ${ }^{73}$ military necessity ${ }^{74}$ and proportionality ${ }^{75}$ this deprivation will not be arbitrary and will thus be allowed. ${ }^{76}$

In practice, this analysis is difficult, especially in the context of targeting in noninternational armed conflicts (NIAC). Based on the principle of distinction, civilians are protected when they do not take part in hostilities and thus may not be targeted. ${ }^{77}$ As military operations now often occur in civilian-populated centres, civilians are increasingly taking part in hostilities directly. ${ }^{78}$ This has resulted in the blurring of the civilian-combatant distinction. ${ }^{79}$ Consequently, peaceful civilians are more likely to fall victim to erroneous or unnecessary targeting ${ }^{80}$ because the concept of direct

65. UNHRC, 'General Comment No. 6: Article 6 (Right to Life)' (30 April 1982) UN Doc No. HR1/GEN/1/Rev.1 (GC 6), para 3.

66. ICCPR art 4; ACHR art 27; ECHR art 15.

67. Human Rights Watch (HRW), 'A Wedding that Became a Funeral - US Drone Attack on Marriage Procession in Yemen' (19 February 2014) <www.hrw.org/report/2014/02/19/weddingbecame-funeral/us-drone-attack-marriage-procession-yemen> accessed 15 March 2017 (HRW, 'US Drone Attack').

68. GC 6 (n 65).

69. See, for example, ICCPR (n 3) art 6(1); UDHR (n 3) art 3; ECHR (n 3) art 2.

70. N Peterson, 'Life, Right To, International Protection' in R Wolfrum (ed), Max Planck Encyclopaedia Of Public International Law (OUP, Oxford 2012) para 16; S Joseph and M Castan, The International Covenant on Civil and Political Rights: Cases, Materials, And Commentary (3rd edn, OUP, Oxford 2013) para 8.04; Camargo (on behalf of Suárez de Guerrero) v Colombia (1982) 2 Selected Decisions of the Human Rights Committee 139, para 13.3. 71. Borelli (n 37) 274.

72. AP I (n 7), arts 44(3), 48; Protocol Additional to the Geneva Conventions of 12 August 1949, and relating to the Protection of Victims of Non-International Armed Conflicts (Protocol II) (adopted 8 June 1977, entered into force 7 December 1978) 1125 UNTS 609 art 13(1).

73. AP I (n 7) art 35(2).

74. Declaration Renouncing the Use, in Time of War, of Explosive Projectiles Under 400 Grammes Weight (1868), Preamble, para 2; General Orders No. 100: The Lieber Code (promulgated 24 April 1863) art 14.

75. AP I (n 7) art 51(5)(b).

76. Nuclear Weapons (n 28) [25].

77. AP I (n 7) art 51(3).

78. Pejic (n 55) 22-3.

79. Ibid.

80. R Millson and D Herman, 'Killing by Drones: Legality under International Law' (The Foundation for Law, Justice and Society, 2015) <www.fljs.org/files/publications/Killing\% 20by\%20Drones-Legality\%20under\%20International\%20Law.pdf> accessed 15 March 2017, 3. 
participation in hostilities is unclear; the meaning and duration of participation is highly debated. ${ }^{81}$ However, when an individual's battlefield status is unclear, he may not be targeted. ${ }^{82}$ Targeting and killing him would violate IHL and constitute an arbitrary deprivation of life. ${ }^{83}$

Since the targeting of such individuals is not allowed, Pejic and Melzer propose the adoption of the law enforcement paradigm in such situations, where States are encouraged to capture rather than kill. ${ }^{84}$ Although lethal force may still be used, the standard of arbitrariness is different under the law enforcement paradigm. The right to life will be violated if the use of force is not 'absolutely necessary' and 'proportionate'. ${ }^{85}$

In conclusion, when weapons kill in non-compliance with IHL, the right to life will also be breached. Conceptually, it is important to note that while constituting a breach of IHRL, the violation of the right to life will generally result from the improper use of these weapons and not from the weapons' inherent nature.

\subsubsection{Drones and killer robots}

Lethal drone strikes in armed conflict are lawful only when they are not arbitrary, that is, when the principles of IHL are upheld. The so-called 'personality strikes', where a known fighter is targeted, may be allowed, as long as they are proportionate. ${ }^{86}$ However, 'signature strikes', where a group of individuals displaying suspicious behaviour which the State links to military activity is targeted, are unlawful. ${ }^{87}$ These result in larger numbers of victims, whereby the principles of proportionality and distinction are violated. ${ }^{88}$ Furthermore, the requirement to take precautions in attacks is also breached, as no care is taken 'to spare the civilian population' ${ }^{89}$ For instance, the USA's strikes in Pakistan targeted civilians merely suspected of taking direct part in hostilities. ${ }^{90}$ The USA clearly violated the principle of distinction by not presuming that they were civilians, thereby depriving them of their lives arbitrarily. ${ }^{91}$

However, while past experience reveals that drones have been used in circumstances where they breached IHL and IHRL, they can, in theory, be employed with precision

81. Melzer (n 49) 43.

82. Ibid 82-3; Pejic (n 55) 26-7.

83. Nuclear Weapons (n 28) [25].

84. Ibid.

85. McCann v United Kingdom App No 18984/91 (ECtHR, 27 September 1995), para 148; Elettronica Sicula SpA (ELSI) (United States of America v Italy) [1989] ICJ Rep 15 [128].

86. 'The Civilian Impact of Drones: Unexamined Costs, Unanswered Questions' (Center for Civilians in Conflict and Human Rights Clinic at Columbia Law School, 2012) <https://web. law.columbia.edu/sites/default/files/microsites/human-rights-institute/files/The\%20Civilian\% 20Impact\%20of\%20Drones.pdf> accessed 15 March 2017 (Civilian Impact of Drones), 8.

87. Ibid.

88. AI, 'The Devil in the Still Undisclosed Detail - Department of Justice White Paper on Use of Lethal Force Against US Citizens Made Public' (6 February 2013) <www.amnestyusa.org/ research/reports/the-devil-in-the-still-undisclosed-detail-department-ofjustice-white-paper-onuse-of-lethal-force-a> accessed 15 March 2017 ('AI, Undisclosed Detail'); Reprieve, 'US Drone Strikes Kill 28 Unknown People for Every Intended Target' (25 November 2014) <www.reprieve. org.uk/press/2014_11_25_us_drone_strikes_kill_28_each_target/> accessed 15 March 2017 ('Reprieve, US Drone Strikes').

89. AP I (n 7) art 57(1).

90. AI, 'Targeted Killings' (n 5).

91. Ibid. 
against lawful targets. Drones are thus not inherently unlawful. Rather, their use, in certain circumstances, can breach the right to life and be unlawful.

Although killer robots' main advantage is their alleged precision, ${ }^{92}$ unless programmed adequately, their computational systems are unable to make sound distinctions between civilians and fighters in NIAC. ${ }^{93}$ Further, proportionality is the most difficult principle to comply with because of its highly contextual applicability. ${ }^{94}$ Combatants must be able to adapt to changing circumstances and make assessments on a case-by-case basis. ${ }^{95}$ Killer robots may not have this flexibility. ${ }^{96}$ Assessing the military necessity of an operation is also a matter of contextual interpretation. ${ }^{97}$ Current empirical evidence suggests that it is doubtful that killer robots can consider the practical implications of a military situation at any given moment. ${ }^{98}$ This means that killer robots may not be capable of complying with the principles of distinction and proportionality. Thus, in circumstances where killer robots would cause killings that violate these basic IHL principles, the right to life would also be breached. ${ }^{99}$

It is, however, not possible to determine with absolute certainty whether killer robots are inherently unlawful. As they have not yet been used, an assessment of their operation is difficult. If killer robots are unable to observe the intricacies of a battlefield and apply the principles of distinction and proportionality, it follows that they are inherently unlawful. However, if killer robots prove to be precise weapons, it might be that they would only breach IHL and IHRL when they are not properly programmed and target protected persons too. In this case, they could not be deemed inherently unlawful - rather, their use would breach IHRL and be unlawful.

\subsection{The prohibition of torture and CIDT}

\subsubsection{The law}

The prohibition of torture and CIDT constitutes jus cogens. ${ }^{100}$ As a peremptory norm, the prohibition is a non-derogable fundamental principle of international law ${ }^{101}$ and

92. PAX, 'Deadly Decisions: 8 Objections to Killer Robots' (26 February 2014) <www.paxfor peace.nl/stay-informed/news/stop-killer-robots-while-we-still-can> accessed 15 March 2017, 11.

93. 'Killer Robots: UK Government Policy on Fully Autonomous Weapons' (Article 36, April 2013) <www.article36.org/wp-content/uploads/2013/04/Policy_Paper1.pdf> accessed 15 March 2017, 2; H-Y Liu, 'Categorization and Legality of Autonomous and Remote Weapons Systems' (2012) 94 (886) International Review of the Red Cross 642.

94. M Schmitt, 'Fault Lines in the Law of Attack' in S Breau and A Jachec-Neale (eds), Testing the Boundaries of International Humanitarian Law (British Institute of International and Comparative Law, London 2006) 293.

95. Ibid.

96. UNGA, 'Report of the Special Rapporteur on Extrajudicial, Summary or Arbitrary Executions' (2013) UN Doc A/HRC/23/47, para 91.

97. Human Rights Watch, 'Losing Humanity: The Case against Killer Robots' (November 2012) <www.hrw.org/sites/default/files/reports/arms1112ForUpload_0_0.pdf> accessed 15 March 2017 (HRW, 'Losing Humanity') 34.

98. Ibid.

99. Ibid.

100. UN Committee against Torture, 'General Comment No. 2: Implementation of Article 2 by States Parties' (24 January 2008) CAT/C/GC/2 (GC 2) paras 1, 5; Questions Relating to the Obligation to Prosecute or Extradite (Belgium v Senegal) [2012] ICJ Rep 422 [99]; Gäfgen v Germany App No 22978/05 (ECtHR, 1 June 2010), paras 97, 107.

101. I Brownlie, Principles of Public International Law (5th edn, OUP, Oxford 1998) 515. 
takes precedence over IHL. ${ }^{102}$ According to Article 1 of the CAT, only the intentional infliction of suffering can constitute torture. Since weapons are not employed with an intent to inflict pain, they do not result in torture.

However, it is submitted that weapons can result in CIDT, which has a lower intensity threshold. ${ }^{103}$ It is widely accepted that CIDT is also jus cogens. ${ }^{104}$ The prohibition covers unintentional and negligent treatment, ${ }^{105}$ and is violated where suffering greater than the 'least possible' is caused. ${ }^{106}$ Moreover, this right protects against mental harm too. ${ }^{107}$ While ill-treatment must attain a minimum threshold of severity to fall under CIDT, ${ }^{108}$ it is submitted that most modern weapons have the capacity to satisfy this hurdle. The severe physical injuries caused by such weapons, ${ }^{109}$ as well as the psychological effects they have on individuals may well constitute CIDT. ${ }^{110}$

\subsubsection{Drones and killer robots}

Drones are known to have caused hundreds of individuals severe physical harm, such as lost limbs or permanent pain-generating injuries. ${ }^{111}$ Empirical evidence of such injuries proves that the great physical pain caused by drones may well reach the threshold of CIDT. ${ }^{112}$

Furthermore, drone strikes do not result in killings or corporal injuries only. They cause mental harm to witnesses and victims' families. ${ }^{113}$ For instance, three children witnessed their grandmother being 'blown to pieces' by a drone strike in Waziristan. ${ }^{114}$ They then had to gather her scattered body parts. The sheer memory of this trauma still causes them great mental suffering in their adult lives. ${ }^{115}$ Moreover, civilians living in areas with frequent drone strikes live in constant fear. ${ }^{116} \mathrm{~A}$ victim from Pakistan recalls, 'We fear that the drones will strike us again [...] my aged parents are often in a state of fear.' ${ }^{117}$ In villages where civilians spot $15-20$ drones daily, ${ }^{118}$ whole

102. Ibid.

103. Ireland v United Kingdom App No 5310/71 (ECtHR, 18 January 1978), para 162.

104. GC 2 (n 100), para 3.

105. M Nowak and E Mcarthur, The United Nations Convention Against Torture: A Commentary (OUP, Oxford 2008) 558.

106. Charles Chitat $N g$ v Canada (1995) 5 Selected Decisions of the Human Rights Committee 94, para 16.4.

107. UNHRC, 'General Comment No. 20: Article 7' (10 March 1992) UN Doc No. HR1/GEN/ 1/Rev.1, para 5; UNCHR, 'Report of the Special Rapporteur on the Question of Torture and Other Cruel, Inhuman or Degrading Treatment or Punishment' The United Nations Special Rapporteur for the Commission on Human Rights, 'Report of 3 July 2001 to the General Assembly on the Question of Torture and Other Cruel, Inhuman or Degrading Treatment or Punishment' (3 July 2001) UN Doc A/56/156, para 8.

108. Ireland $v$ United Kingdom (n 103) para 162.

109. HRW, 'US Drone Attack' (n 67).

110. Ibid.

111. Ibid.

112. Ibid.

113. AI, 'Targeted Killings' (n 5) 6.

114. AI, 'US Drone Strikes' (n 58) 18.

115. Ibid.

116. Civilian Impact of Drones (n 86) 21.

117. Ibid 24.

118. Ibid. 
communities live in terror, which has taken 'a psychological toll' on them. ${ }^{119}$ This severe type of mental harm effectively constitutes CIDT as envisaged in CAT.

Further, consider the following scenario. A drone strike kills a fighter instantly, without causing him physical pain and without any witnesses. In this utopic case, the drone strike would not result in CIDT. However, in the real world, there is no battlefield where this scenario occurs. ${ }^{120}$ Drones often cause severe pain and lasting psychological trauma. This harsh reality may tempt one to contend that drones are inherently unlawful and should therefore never be used. However, as mentioned above, in theory, it is possible to use drones in a 'clean' manner, where, despite the killing of the targeted fighter, no physical or mental harm is caused. Therefore, the fact that CIDT was caused in most situations when drones have been employed in the past does not automatically render drones inherently unlawful. Thus, drones will result in CIDT only in circumstances where their use causes severe physical or mental suffering.

A CIDT-related assessment of killer robots is difficult because they have not been used yet. ${ }^{121}$ However, due to their intended lethal nature, ${ }^{122}$ there is no reason to believe that they would not have the same effect as drones. Empirical evidence suggests that killer robots are just as capable of causing severe corporal and mental harm. ${ }^{123}$ Moreover, the dire consequences of killer robots would fall on civilians once more, as their widespread use would cause them to live in fear and result in severe mental suffering. ${ }^{124}$ Thus, where killer robots cause serious physical or mental harm, the prohibition of CIDT will be breached.

\section{THE LEGALITY OF NEW WEAPONS: AN OVERALL APPRAISAL}

This paper has demonstrated that the ICRC's New Weapons Review is incomplete because IHRL was not included in the assessment of the legality of new weapons despite its applicability in armed conflict. The paper then analysed the legality of two modern weapons, drones and killer robots, from the perspective of the right to life and the prohibition of torture and CIDT. First, it has been determined that the right to life will be violated when the use of drones or killer robots does not comply with IHL. Secondly, the paper argued that, in circumstances where they cause severe physical or mental suffering, drones and killer robots result in CIDT.

As 'the guardian of IHL', the ICRC naturally places a heavier focus on humanitarian aspects when addressing an armed conflict. ${ }^{125}$ However, the ICRC also has a 'watchdog' function, ${ }^{126}$ whereby it has a responsibility to ensure that, in an armed conflict, all relevant international law is respected, including IHRL. The ICRC has a duty to promote and disseminate all applicable laws. ${ }^{127}$ Therefore, the paper recommends that the ICRC reassesses its New Weapons Review, so as to clearly state the need

119. Ibid.

120. AI, Undisclosed Detail (n 88); Reprieve, US Drone Strikes (n 88).

121. Key Areas for debate (n 64).

122. AI, Undisclosed Detail (n 88); Reprieve, US Drone Strikes (n 88).

123. Ibid.

124. HRW, 'Losing Humanity' (n 97) 39-40.

125. Y Sandoz, 'The International Committee of the Red Cross as Guardian of International Humanitarian Law' (International Committee of the Red Cross, 31 December 1998) <www. icrc.org/eng/resources/documents/misc/about-the-icrc-311298.htm> accessed 15 March 2017.

126. Ibid.

127. Ibid. 
to consider weapons from a human rights perspective as well. This paper made a modest attempt at providing a starting point for such a review, as it sought to complement the ICRC's guidelines by providing a practical framework for a human rights assessment by reference to specific weapons.

In particular, the author insists on the express consideration of IHRL to reinforce its fundamental character in the international community. Certain States still assume cynically that IHRL does not apply in armed conflict, which undermines the significance of human rights. The author, therefore, urges the ICRC to engage actively in combating this assumption by revising its New Weapons Review. Although the ICRC generally recognises the existence of IHRL in armed conflict, its applicability must be stressed at every opportunity. It is thus imperative that IHRL formally become part of the ICRC's assessment of the legality of new weapons. 